Article

\title{
Antennal Morphology and Sexual Dimorphism of Antennal Sensilla in Callitettix versicolor (Fabricius) (Hemiptera: Cercopidae)
}

\author{
Qing Zhu ${ }^{1} \oplus$, Nan $W u^{1}$, Jolanta Brożek ${ }^{2}$ and Wu Dai ${ }^{1, *(1)}$ \\ 1 Key Laboratory of Plant Protection Resources and Pest Integrated Management of the Ministry of Education, \\ College of Plant Protection, Northwest A\&F University, Yangling 712100, Shaanxi, China; \\ 18392861169@163.com (Q.Z.); wn1114691213@163.com (N.W.) \\ 2 Department of Zoology, Faculty of Biology and Environmental Protection, University of Silesia, Bankowa 9, \\ 40-007 Katowice, Poland; jolanta.brozek@us.edu.pl \\ * Correspondence: daiwu@nwsuaf.edu.cn
}

Received: 28 January 2019; Accepted: 15 February 2019; Published: 19 February 2019

check for updates

\begin{abstract}
The rice spittlebug Callitettix versicolor (Fabricius) is an important pest of rice and maize in South Asia and causes severe economic damage. To provide background information for chemical ecology studies, the fine morphology of antennae and the types and distribution of the sensilla on the male and female antennae of Callitettix versicolor (Fabricius) are investigated by means of scanning electron microscopy (SEM). Results show that the antenna is filiform and composed of three segments: a scape, a pedicel, and a flagellum. The female antennae are slightly shorter than the male antennae. In both sexes, four types and nine subtypes of sensilla were observed: sensilla basiconica (SB1, SB2), sensilla campaniformia (SCa1, SCa2 and SCa3), sensilla coeloconica (SCo1, SCo2 and SCo3) and sensilla trichodea (ST). In addition, sensilla coeloconica (SCo1) are observed on the membrane of the top of the pedicel in Cercopidae for the first time. Sexual dimorphism mainly occurs in variation in the number of sensilla coeloconica ( $\mathrm{SCo} 2, \mathrm{SCo} 3)$ on the bulb-shaped portion of the flagellum and in the shape of sensilla basiconica (SB2). There are significantly more sensilla coeloconica in males than in females. The external structure and distribution of these sensilla are compared to those of other cercopids and possible functions of the antennal sensilla are discussed.
\end{abstract}

Keywords: Auchenorrhyncha; antennal sensilla; fine morphology; scanning electron microscopy

\section{Introduction}

Members of the superfamily Cercopoidea (Hemiptera) are widely distributed, predominantly in the tropical and subtropical regions of the world, and consist of five families (Cercopidae, Aphrophoridae, Clastopteridae, Machaerotidae and Epipygidae). The family Cercopidae, known as froghoppers, includes approximately 1500 species in 150 genera [1]. Many of these species are economically significant pests of important agricultural crops. Callitettix versicolor (Fabricius) is one of the species harmful to agricultural crops and causes severe economic damage to rice and maize in China, India, Malaysia, Myanmar, Thailand, and Vietnam [2]. Therefore, in the study of such pest species, it is very important to know the sensory systems of their antennae, which are used for the recognition of host plants.

Insect antennae are segmented appendages that are well-equipped with a wide variety of antennal sensilla and function primarily in chemoreception, thermoreception and hygroreception. Antennae play a crucial role in insect behavior, including host location and recognition, as well as mating behavior [3-8]. Moreover, the form of the antenna varies considerably depending on its precise 
function and the remarkable difference on sensory equipment, which has the potential value for taxonomic and phylogenetic analyses [9].

Abundant data are available on some aspects of antennae morphology of Hemiptera based on light and scanning electron microscopy [10-16]. Nevertheless, the antennal sensilla of cercopoid species have received only sporadic attention. Previous studies of the antennae in Cercopoidea have mostly focused upon the external comparative morphology of different cercopoid species with the aim of elucidating their taxonomic relationships $[1,17]$ and the antennal sensilla of a few species have been studied to infer their functions $[18,19]$.

Cercopoids' antennae perform crucial functions in their life cycle, with the sensillar equipment fine-tuned by strong selection $[19,20]$. The clarification of the sensory mechanisms of cercopid antennae can help to understand their ecology and biology, especially where there are differences between the sexes. Some characteristics and function of the sensilla can be inferred from their morphology and anatomy $[4,21]$. This is best accomplished using scanning electron microscopy (SEM) techniques.

Exterior variation of the different types of sensilla and their distribution on the pedicel and flagellum in the Hemipteran infraorder Fulgoromorphan (planthoppers), have received more attention, as these structures have a potential value in taxonomic and phylogenetic analysis [9,22-26]. Cercopoid antennae also offer an abundance of structures that provide excellent taxonomic and phylogenetic characters [1,17]. Paladini et al. [27] reconstructed phylogenetic relationships for New World spittlebug genera based on morphological data, including a few characters of the antennae (shape of basal body of flagellum, size of basal body of flagellum relative to pedicel, length and density of setae on pedicel, arista of basal body of flagellum, and length of arista compared to pedicel) for some species (Maxantonia rubescens, Sphenoclypeana parana, Sphenorhina rubra, Kanaima fluvialis, and Notozulia entreriana) of Ischnorhininae. Moreover, there are variations in the antennal structure among genera and in some cases among species. Therefore, further study of the antennae and their sensilla will contribute to a deeper understanding of the phylogenetic relationships within the Cercopoidea [8,22,27-32]. Unfortunately, at present there is a paucity of morphological and anatomical data on antennae and antennal sensilla in species of the subfamily Cercopinae, an old and paraphyletic group. More detailed investigations with expanded taxonomic sampling are needed to address longstanding questions pertaining to generic and tribal relationships within each major spittlebug lineage [33].

The aim of the present study was to provide the first detailed fine morphological characterization of the antennae of Callitettix versicolor using light and scanning electron microscopy (SEM), because this species is a pest, and belongs to the phylogenetically problematic Old World subfamily Cercopinae. The fine structure, location and distribution of different sensilla types in both males and females were investigated to document any differences between the sexes (unusual in this group of insects), comparing the sexes and discussing the possible function of these sensilla with the aim of fully unveiling fine structural details. These data provide an important starting point and are complementary to further physiological and behavioural studies on C. versicolor and other cercopoid species, and may be useful for the future study of taxonomic and phylogenetic analysis of Cercopidae.

\section{Materials and Methods}

\subsection{Insect Collecting}

All Callitettix versicolor (Fabricius) specimens used in this study were collected in the Guizhou Province, China and preserved in $70 \%$ ethanol and stored at $4{ }^{\circ} \mathrm{C}$.

Heads with antennae were separated from the rest of the body and rinsed in $70 \%$ ethanol in an ultrasonic cleaning. Dehydration was achieved with a graded ethanol series of $75 \%, 80 \%, 90 \%$, and $95 \%$ each for $20 \mathrm{~min}$ and twice in $99.9 \%$ ethanol solutions for $30 \mathrm{~min}$. The $99.9 \%$ ethanol was then substituted successively by mixing alcohol and tert-butyl ethanol with in proportions of 3:1, 1:1 and 1:3. Finally, specimens were placed in pure tert-butyl ethanol for $30 \mathrm{~min}$. Specimens were dried in a freeze-drier (VFD-21S, SHINKKU VD, Tokyo, Japan) for $3 \mathrm{~h}$. Thereafter, the antennae were removed 
from the dried samples under a stereomicroscope (Olympus SZX10, Olympus, Tokyo, Japan) and placed on aluminum stubs in various positions using double-sided sticky tape. The antennae were sputter-coated with gold-palladium (MSP-1S, Hitachi, Tokyo, Japan) and examined and observed at $15 \mathrm{kV}$ in a Nova nano SEM450. Antennae of male and female adults were observed for comparison.

\subsection{Image Processing and Morphometric Measurement}

Photographs and SEMS were observed and measured after being imported into Adobe Photoshop CS6. The sensilla were classified according to their external morphology, distribution and presence or absence of pores. To characterize the sensilla, we used the nomenclature proposed by Schneider [21] and Zacharuk [3,34].

\section{Results}

\subsection{Gross Morphology of Antennae}

The antennae are inserted in the antennal foveae on the head capsule at the side of the postclypeus and below the antennal ledges (Figure 1A). The gross morphology is similar in the male and female, consisting of three segments: a basal scape, a cylindrical pedicel and a long, filiform flagellum (Figure 1B). No significant differences were found in antennal shape between males and females. Specifically, the entire length of antennae was $1521.32 \pm 10.92 \mu \mathrm{m}$ in females $(n=5)$, and $1562.63 \pm 11.60 \mu \mathrm{m}$ in males $(n=5)$. The antennal segments were slightly longer in adult males than females, with the exception of the scape.
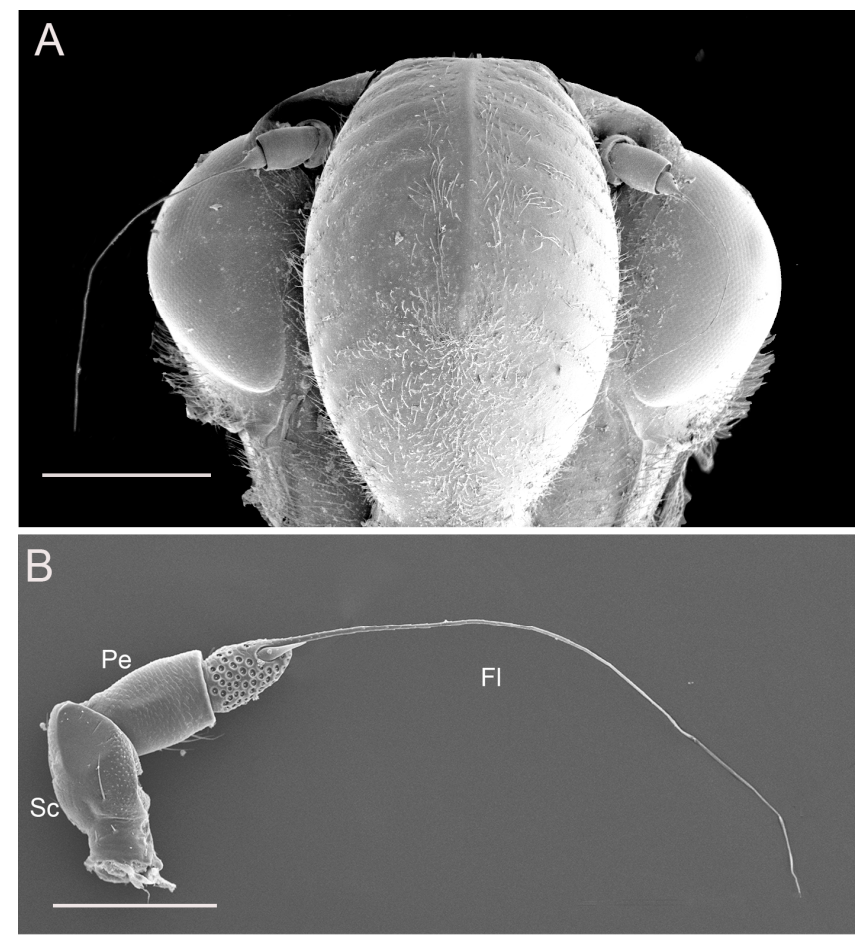

Figure 1. Scanning electron microscopy (SEM) images of Callitettix versicolor (Fabricius) female antenna. (A) Fronto-ventral view of the head capsule showing the insertion of the antennae and their relative position; (B) General view of the antenna showing the scape (Sc), the pedicel (Pe) and the flagellum (Fl). Scale bars: $A=500 \mu \mathrm{m} ; \mathrm{B}=250 \mu \mathrm{m}$.

The scape, which connects to the antennal socket where it functions as the fulcrum for the movement of the antenna, is about $260 \mu \mathrm{m}$ long, irregular in shape, and prominently constricted around the base (Figure 2A-D). The outer margin of the scape is conspicuously concaved in the 
apical half (Figure 2B); the inner margin is slightly convex, with scattered small imbricate papillae and sparsely covered with sensilla (Figure 2D). The dorsal surface is slightly convex with scattered small imbricate papillae (Figure 2C), while the ventral surface appears flat and smooth posteriorly (Figure 2A). The apex of scape is irregular in shape with the relative protrusion of the dorsal and ventral margin, which can serve a protective function by holding part of the pedicel. Therefore, the scape-pedicel joint is a ginglymus (hinge joint), indicating that the primary movement of the pedicel is in a single plane (Figure 2A,C).
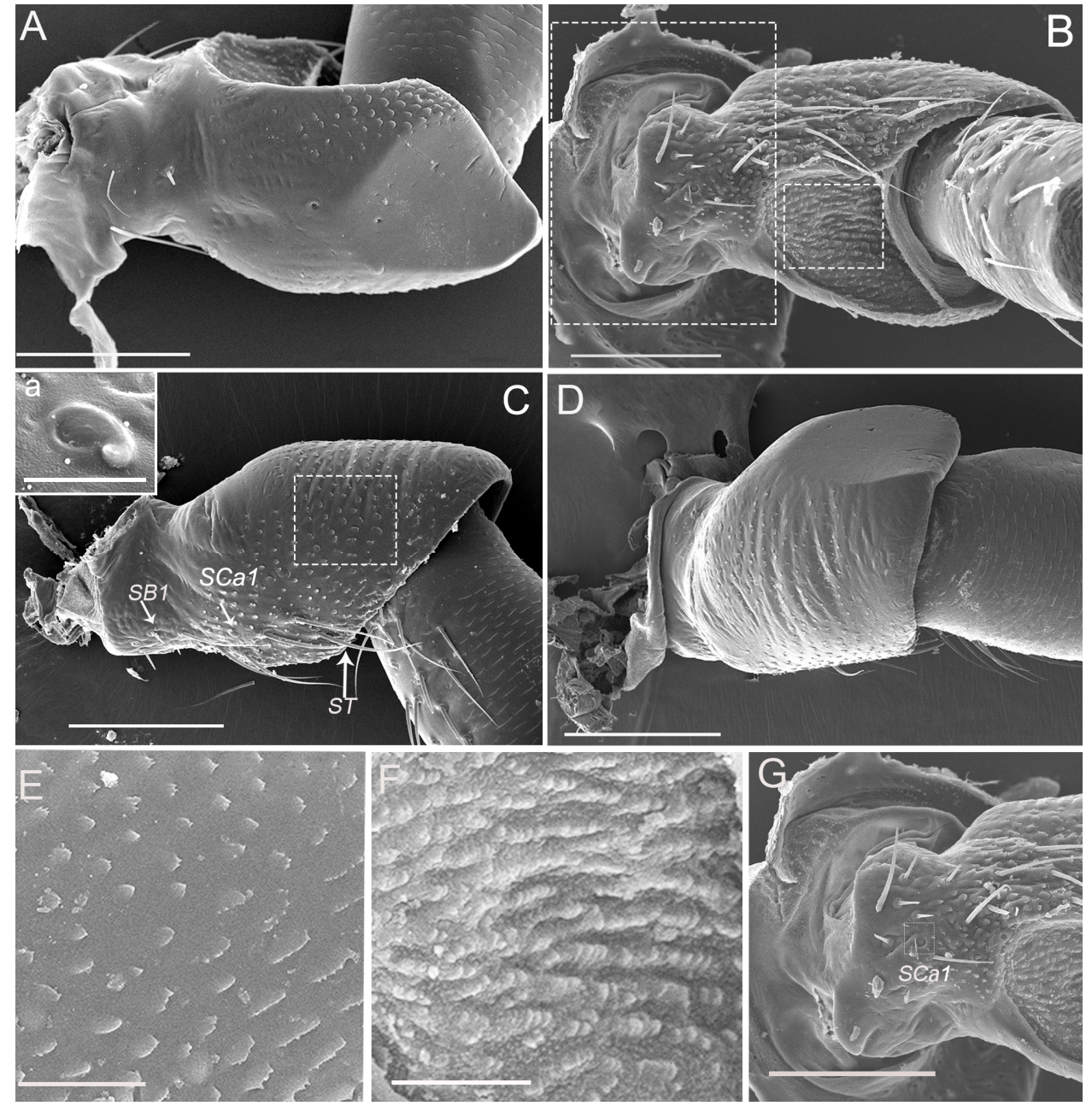

Figure 2. Micrographs showing the scape of an adult Callitettix versicolor's (Fabricius) right antenna. (A) Ventral view; (B) Right lateral view; (C) Dorsal side showing sensilla trichodea (ST), sensilla basiconica (SB1) and sensilla campaniformia (SCa1); a. High magnification image of SCa1; (D) Left lateral view; (E) High magnification image of scape surface showing imbricate papillae, indicated by the rectangle given in (C); (F) High magnification image of the surface of concave on the scape, indicated by the small rectangle given in B); (G) High magnification image showing the antenna inserted in antennal foveae on the head capsule, the positions of the images are indicated by the big rectangle given in (B). Scale bars: $A, B, C, D=100 \mu \mathrm{m} ; E, F=25 \mu \mathrm{m} ; \mathrm{G}=100 \mu \mathrm{m} ; \mathrm{a}=5 \mu \mathrm{m}$.

The pedicel, connected proximally to the concave distal end of the scape and distally to the bulb-shaped portion of the flagellum, is a short (about $200 \mu \mathrm{m}$ ) and generally cylindrical segment, slightly widened distally, wrinkled with numerous transverse small imbricate papillae and covered with several sensilla trichodea on the outer surface (Figure 3A-D). The apical concave portion of the pedicel is encircled by concentrically arranged cuticular ridges (Figure 4A). 

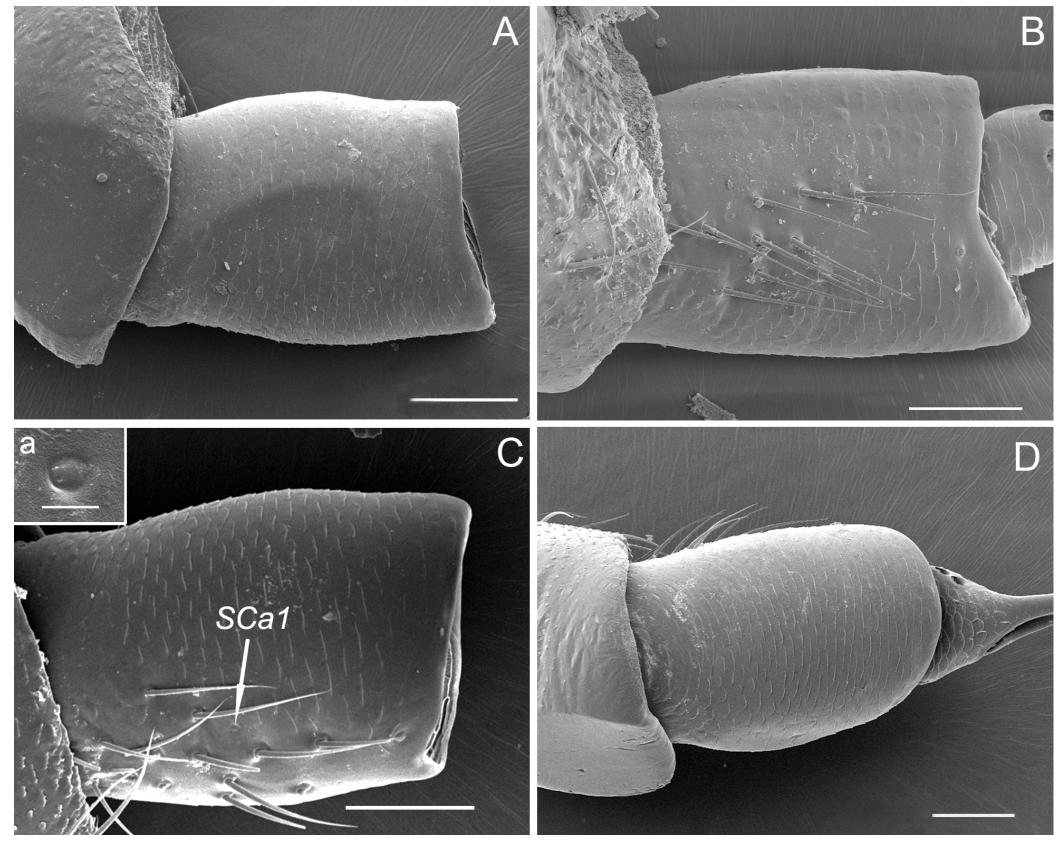

Figure 3. SEM micrographs showing the pedicel of adult Callitettix versicolor (Fabricius) right antenna. (A) Ventral view; (B) Right lateral view showing sensilla trichodea (ST); (C) Dorsal view, a. high magnification image of SCa1; (D) Left lateral view. Scale bars: A, B, C, D = 50 $\mu \mathrm{m} ; \mathrm{a}=5 \mu \mathrm{m}$.

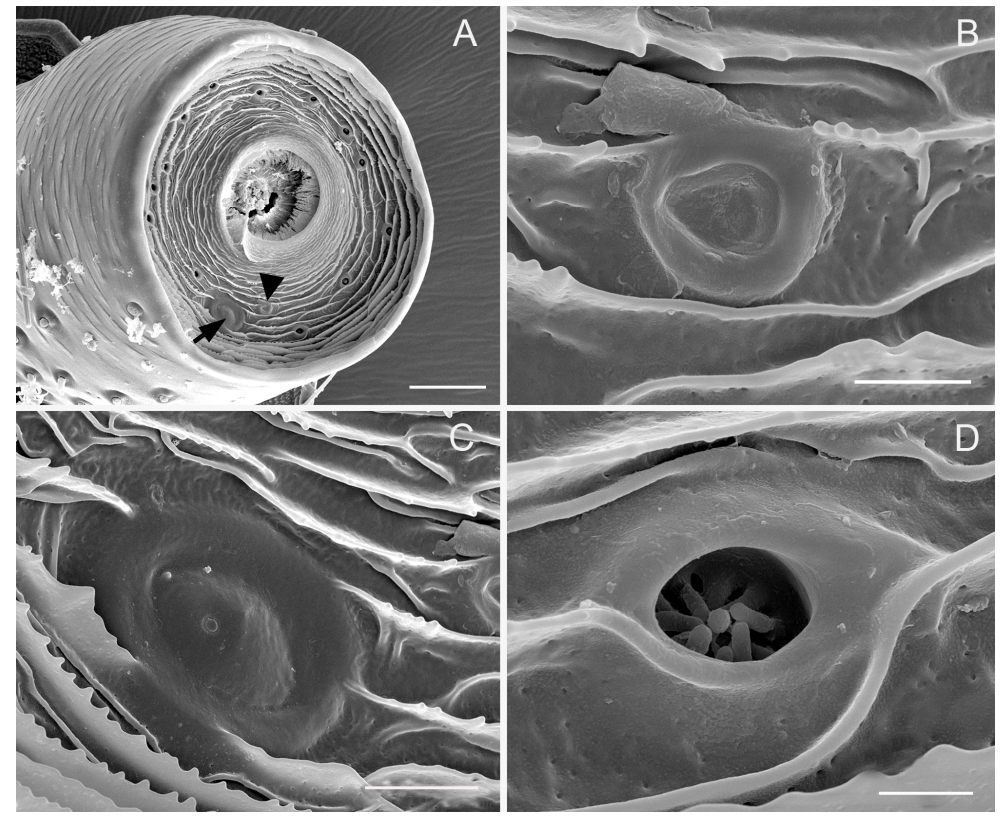

Figure 4. Antennal structures on the apical surface of the pedicel of adult Callitettix versicolor (Fabricius). (A) General view of the apical surface of the pedicel (black triangle indicates SCa2 and black arrow indicate SCa3), concentrically arranged cuticular ridges are visible; (B) High magnification image of sensilla campaniformia 1 (SCa1); (C) High magnification image of sensillum campaniformium 3 (SCa3); (D) High magnification image of sensillum coeloconicum (SCo1). Scale bars: A = $25 \mu \mathrm{m} ; \mathrm{B}=2.5 \mu \mathrm{m}$; C $=5 \mu \mathrm{m} ; \mathrm{D}=1.5 \mu \mathrm{m}$.

The flagellum is divided into two distinct portions, an expanded basal bulb-shaped portion and a threadlike apical arista (Figure 1A,B). The bulb-shaped portion is covered with many sensory units (Figure 5A-D, and Figure 6A-D) while the threadlike arista is not segmented and is covered with imbricate papillae in half base (Figure $7 \mathrm{~A}-\mathrm{D})$. 

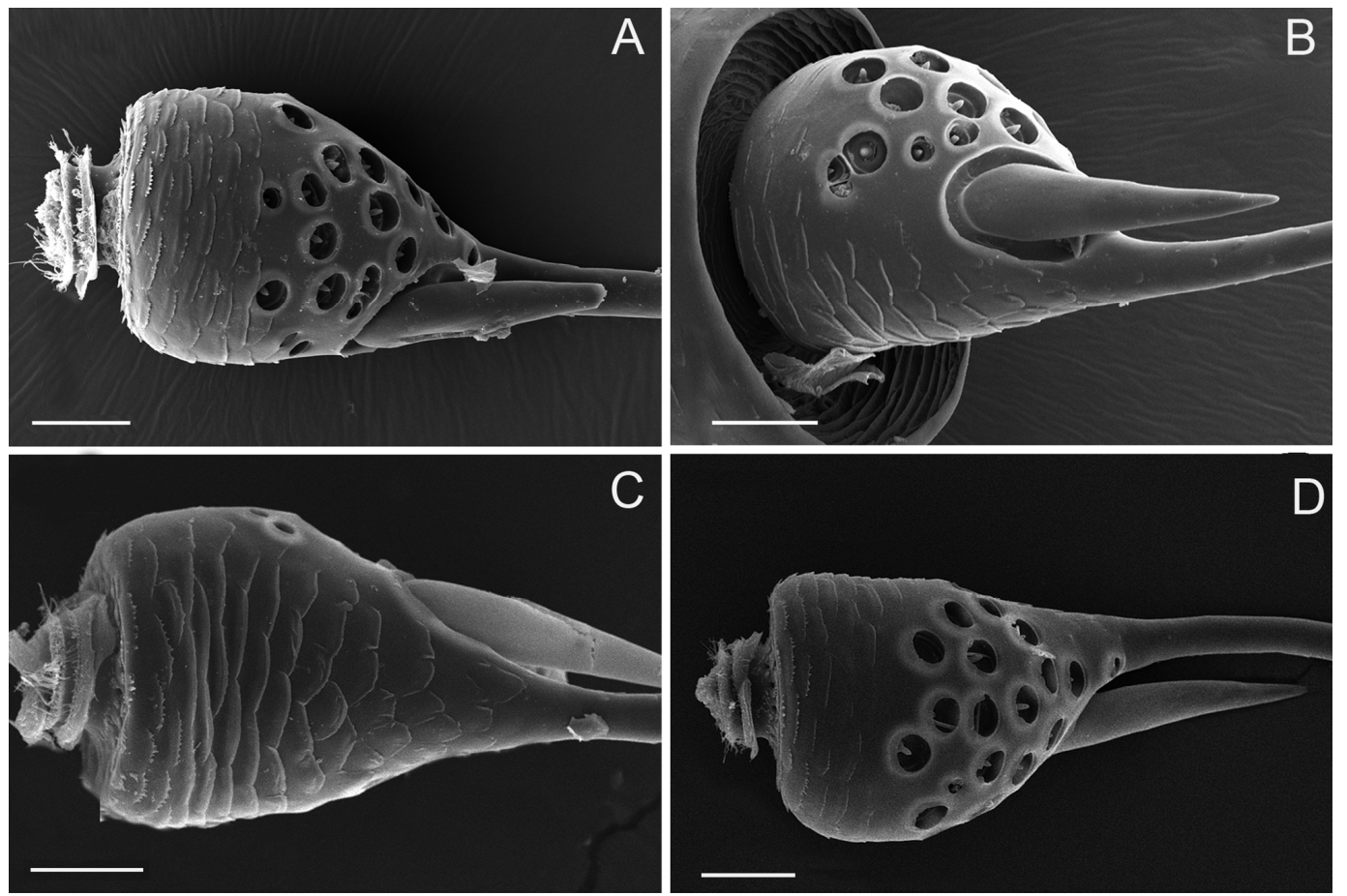

Figure 5. SEM micrographs showing the bulb-shaped portion of the flagellum in an adult female Callitettix versicolor's (Fabricius) antenna. (A) Posterior side; (B) Ventral side; (C) Anterior side; (D) Dorsal side. Scale bars: A, B, C, D = $25 \mu \mathrm{m}$.
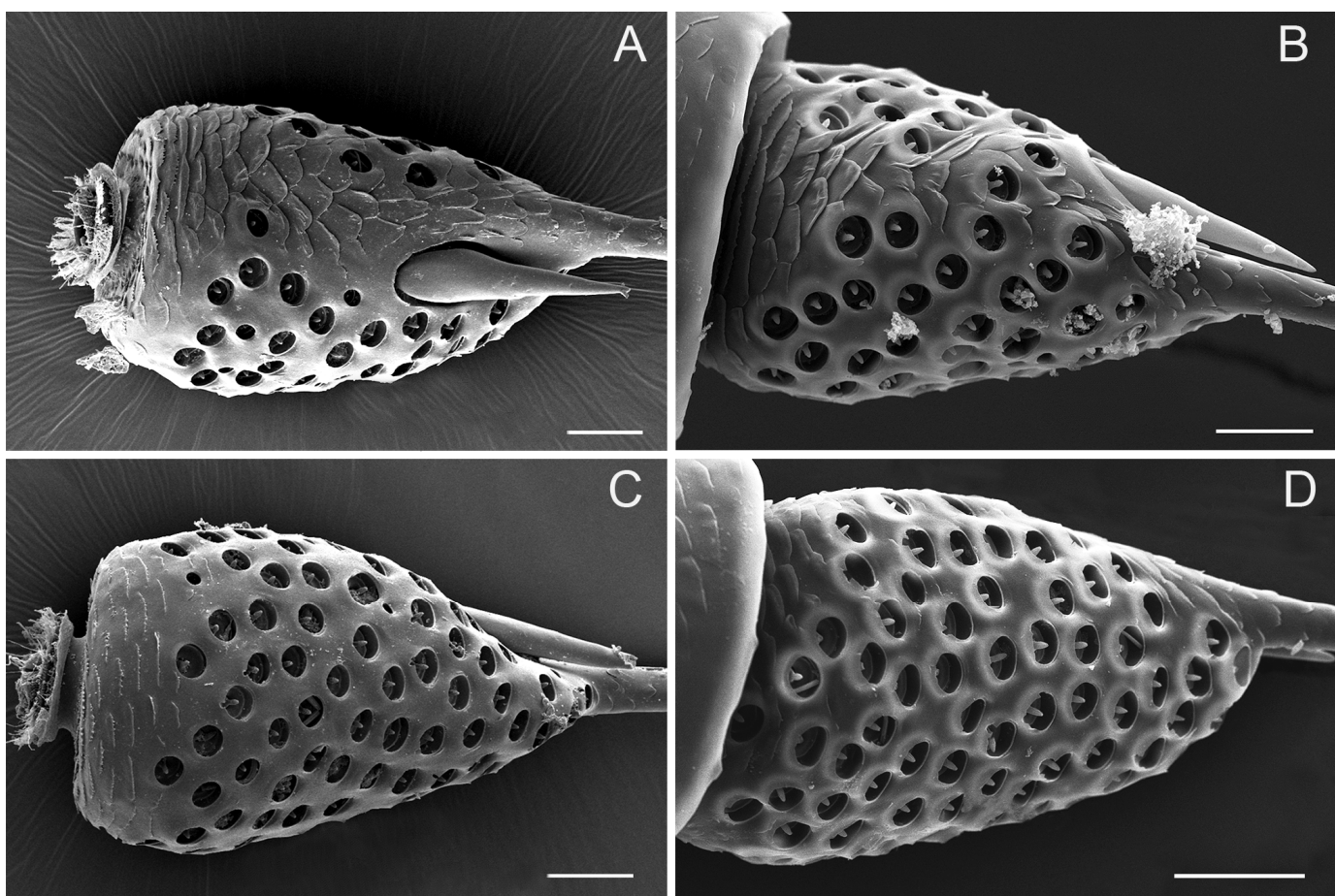

Figure 6. SEM micrographs showing a bulb-shaped portion of flagellum in an adult male Callitettix versicolor's (Fabricius) antenna. (A) Ventral side; (B) Anterior side; (C) Dorsal side; (D) Posterior side. Scale bars: A, B, C, D = 25 $\mu \mathrm{m}$. 

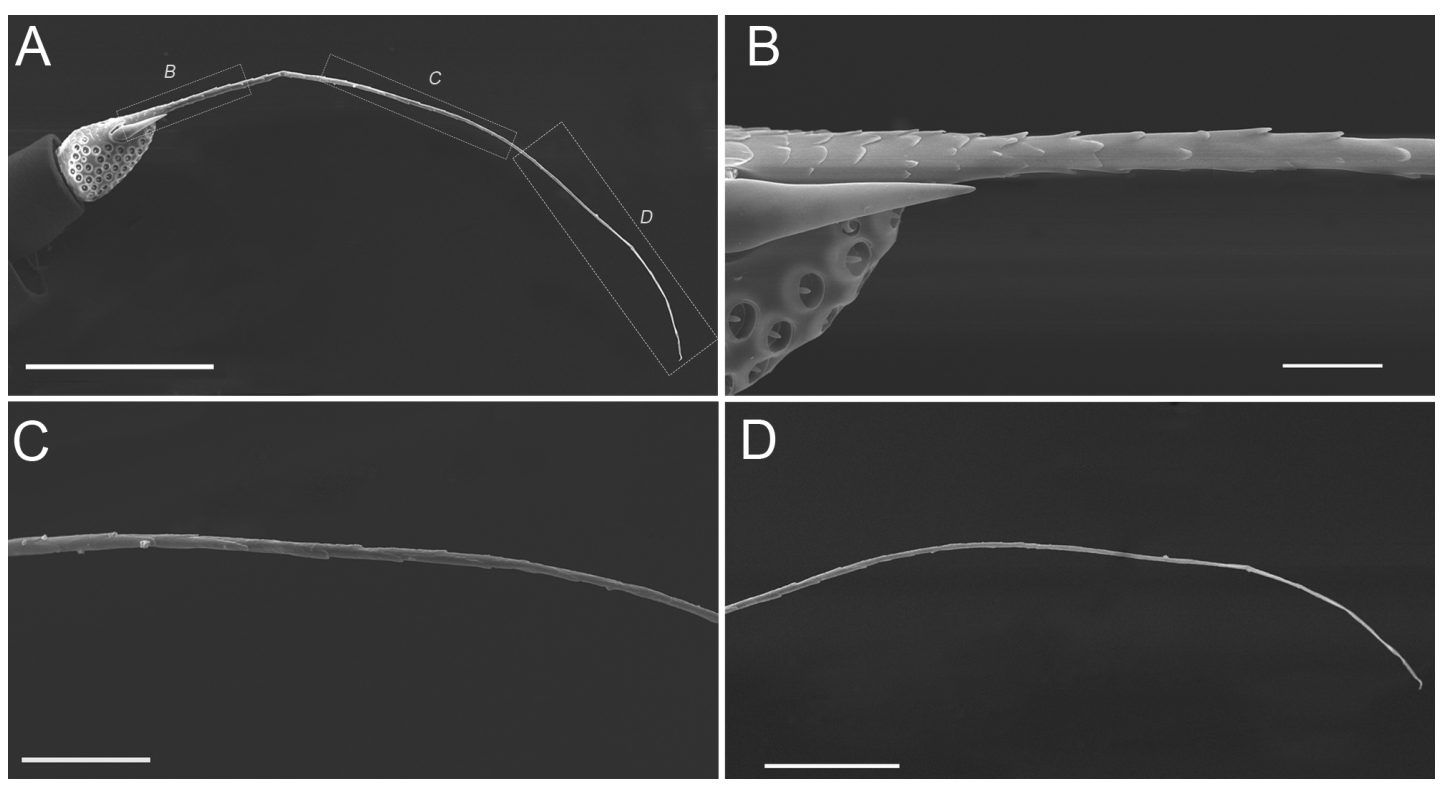

Figure 7. SEM micrographs showing the flagellum of an adult Callitettix versicolor (Fabricius). (A) Entire flagellum consisting of the bulb-shaped portion and apical arista; (B) High magnification image of the base showing apical arista covered with imbricate papillae; (C) High magnification image of the middle showing apical arista with imbricate papillae decreasing gradually; (D) High magnification image of apical half showing apical arista without imbricate papillae. Positions of images (B-D) are indicated by lettered rectangles given in (A). Scale bars: $A=250 \mu \mathrm{m} ; B=25 \mu \mathrm{m} ; C=50 \mu \mathrm{m} ; \mathrm{D}=100 \mu \mathrm{m}$.

\subsection{Sensilla Types}

Four types and nine subtypes of sensilla are present: sensilla trichodea (ST) observed only on the scape and pedicel, two subtypes of sensilla basiconica (SB1, SB2) based on structure and size, three subtypes of sensilla coeloconica (SCo1, $\mathrm{SCo} 2, \mathrm{SCo} 3$ ) which differ in size and structure, and three subtypes of sensilla campaniformia (SCa1, $\mathrm{SCa} 2, \mathrm{SCa} 3)$ based on size.

There is apparent sexual dimorphism in antennal sensilla abundance and distribution.

\subsection{Sensilla Trichodea (ST)}

Sensilla trichodea grouped into a cluster are mainly concentrated on the outer margin of the scape and pedicel (Figure 2B,C and Figure 3B,C). ST are long, straight or slightly curved toward the apex of the segment (Figure 3B,C and Figure $8 \mathrm{C}$ ). Each sensillum trichodeum inserts in a flexible socket, which is slightly elevated above the surrounding cuticle. Each sensillum exhibits longitudinal grooves that spiral slightly and extend from the base to the remaining $2 / 3$, and gradually fade away to the tip (Figure 2C, Figure 3B, and Figure 8C,D). The lengths of these sensilla are $56.33 \pm 3.85 \mu \mathrm{m}$ (Table 1). There are no significant differences between the male and female in length. 

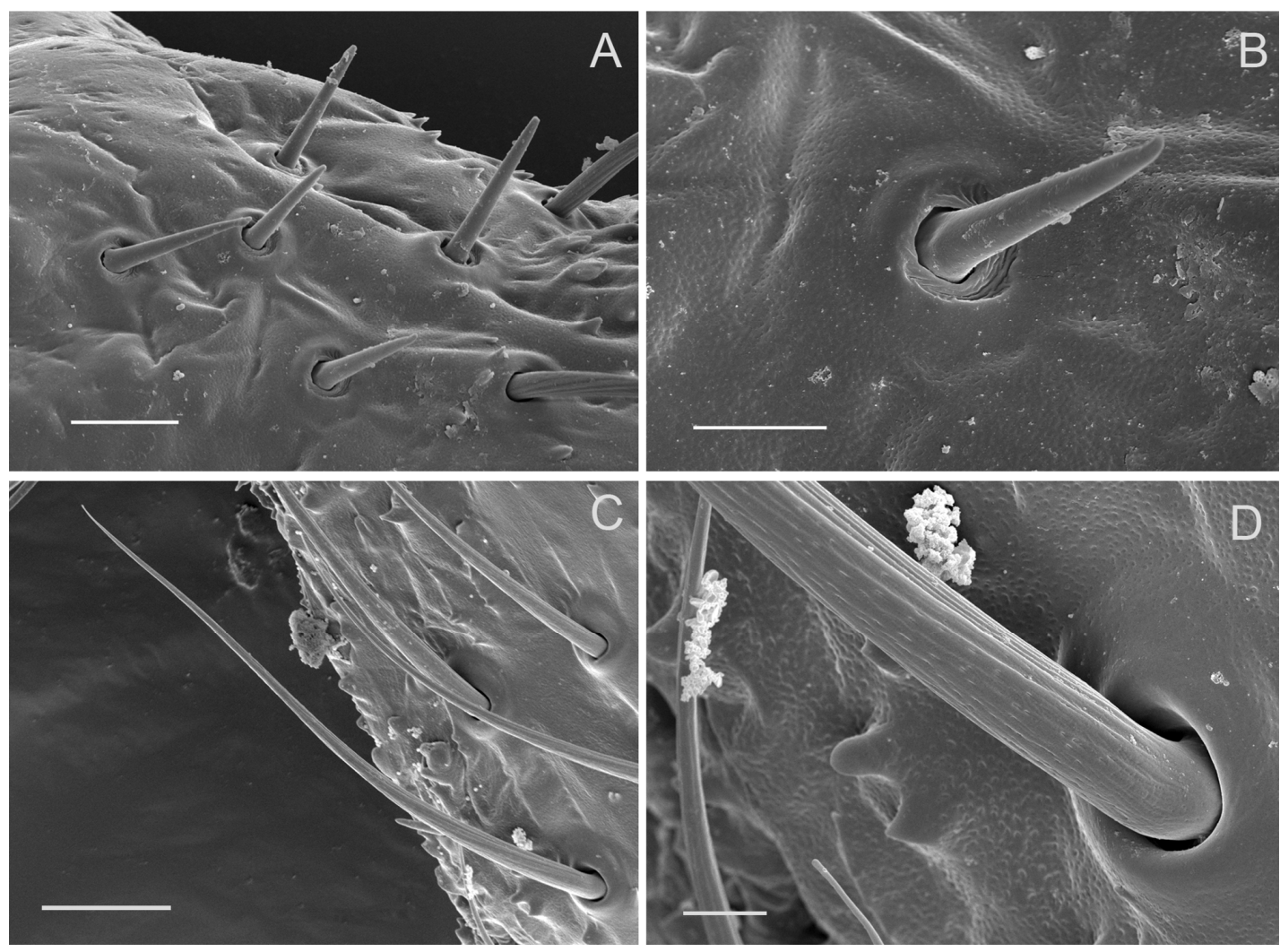

Figure 8. Antennal sensilla on scape and the pedicel of adult Callitettix versicolor (Fabricius). (A) Base of scape showing distribution of sensilla basiconica 1; (B) High magnification of sensilla basiconica 1 (SB1); (C) Sensilla trichodea (ST); (D) High magnification image of the base of sensilla trichodea (ST) showing longitudinal grooves. Scale bars: $A=10 \mu \mathrm{m} ; \mathrm{B}=5 \mu \mathrm{m} ; \mathrm{C}=15 \mu \mathrm{m} ; \mathrm{D}=2.5 \mu \mathrm{m}$.

Table 1. Morphometric data for various antennae sensilla of adult Callitettix versicolor (Fabricius). Data are mean $\pm \mathrm{SE}$ values obtained from scanning electron microscopy. $\mathrm{N}$ = sample number; $\mathrm{NA}$ : not applicable.

\begin{tabular}{|c|c|c|c|c|c|}
\hline Sensilla Type & Distribution & Length $(\mu \mathrm{m})$ & $\begin{array}{c}\text { External } \\
\text { Diameter }(\mu \mathrm{m})\end{array}$ & $\mathbf{N}$ & Amount \\
\hline Sensilla trichodea & $\begin{array}{l}\text { Scape and } \\
\text { pedicel }\end{array}$ & $56.33 \pm 3.85$ & $2.71 \pm 0.18$ & 7 & $24-30$ \\
\hline Sensilla basiconica 1 & Scape & $11.96 \pm 1.12$ & $2.32 \pm 0.07$ & 7 & $6-7$ \\
\hline Sensilla basiconica 2 & Flagellum & $\begin{array}{l}57.08 \pm 2.84(\text { ( ) }) \\
72.10 \pm 2.33\left(\sigma^{7}\right)\end{array}$ & $\begin{array}{l}20.37 \pm 0.99 \\
18.49 \pm 0.63\end{array}$ & 5 & 1 \\
\hline Sensilla campaniformia 1 & $\begin{array}{l}\text { Scape and } \\
\text { pedicel }\end{array}$ & NA & $4.67 \pm 0.56$ & 5 & 1 \\
\hline Sensilla campaniformia 2 & Tip of pedicel & NA & $5.91 \pm 0.75$ & 5 & 1 \\
\hline Sensilla campaniformia 3 & Tip of pedicel & NA & $12.55 \pm 1.01$ & 5 & 1 \\
\hline Sensilla coeloconica 1 & Pedicel & NA & $2.17 \pm 0.36$ & 8 & 13 \\
\hline Sensilla coeloconica 2 & Flagellum & NA & $4.37 \pm 0.58$ & $\begin{array}{l}8(\text { () } \\
8\left(0^{\top}\right)\end{array}$ & $\begin{array}{l}3-4 \\
4-6\end{array}$ \\
\hline Sensilla coeloconica 3 & Flagellum & NA & $8.03 \pm 1.02$ & $\begin{array}{l}8(\text { (ㅇ) } \\
8\left(0^{7}\right)\end{array}$ & $\begin{array}{c}16-18 \\
100-106\end{array}$ \\
\hline
\end{tabular}

\subsection{Sensilla Coeloconica (SCo)}

Sensilla coeloconica (SCo) cover a bulb-shaped portion of the flagellum and the membrane on the top of the pedicel (Figure 4D, Figure 5A-D, and Figure 6A-D). Sensilla coeloconica are peg-in-pit sensilla, consisting of a central peg set on the bottom wall of a chamber sunken into the opening cavity (Figure 4D, and Figure 9C,D). Based on the differences in the central peg, they are divided into SCo1, 
SCo2 and SCo3. In SCo2, the peg is smooth and broad basally, subapically constricted and apically acute (Figure 9C). The pit has an external diameter of $4.37 \pm 0.58 \mu \mathrm{m}$ (Table 1 ); the base of the sensillum is inserted at the bottom of the cavity. In SCo3, the central peg is usually broad basally, subapically constricted and apically acute, with 9-12 apical groove, while the proximal half of the cuticular shaft is smooth externally (Figure 9D). The pit has an external diameter of $8.03 \pm 1.02 \mu \mathrm{m}$ (Table 1); the base of the sensillum was inserted at the bottom of the cavity. A significant difference in the quantity of sensilla between males and females was observed. In the female, there were 19-21 sensilla coeloconica including SCo2 and SCo3, located at the upper, ventromedial side of the expanded flagellar base. In males, the bulb-shaped portion was surrounded by sensilla coeloconica SCo2 and SCo3 in all directions and there were approximately 105-111 (Figure 5A-D and Figure 6A-D). Their positions may vary slightly from one individual to another. Compared with SCo2 and SCo3, SCo1 appears on the membrane of the top of the pedicel and each have an opening in which many scattered pegs are set on the bottom wall and gradually gather together (Figure 4A,D). The amount of SCo1 are approximately 13. The pit has an external diameter of $2.17 \pm 0.36 \mu \mathrm{m}$ (Table 1$)$.
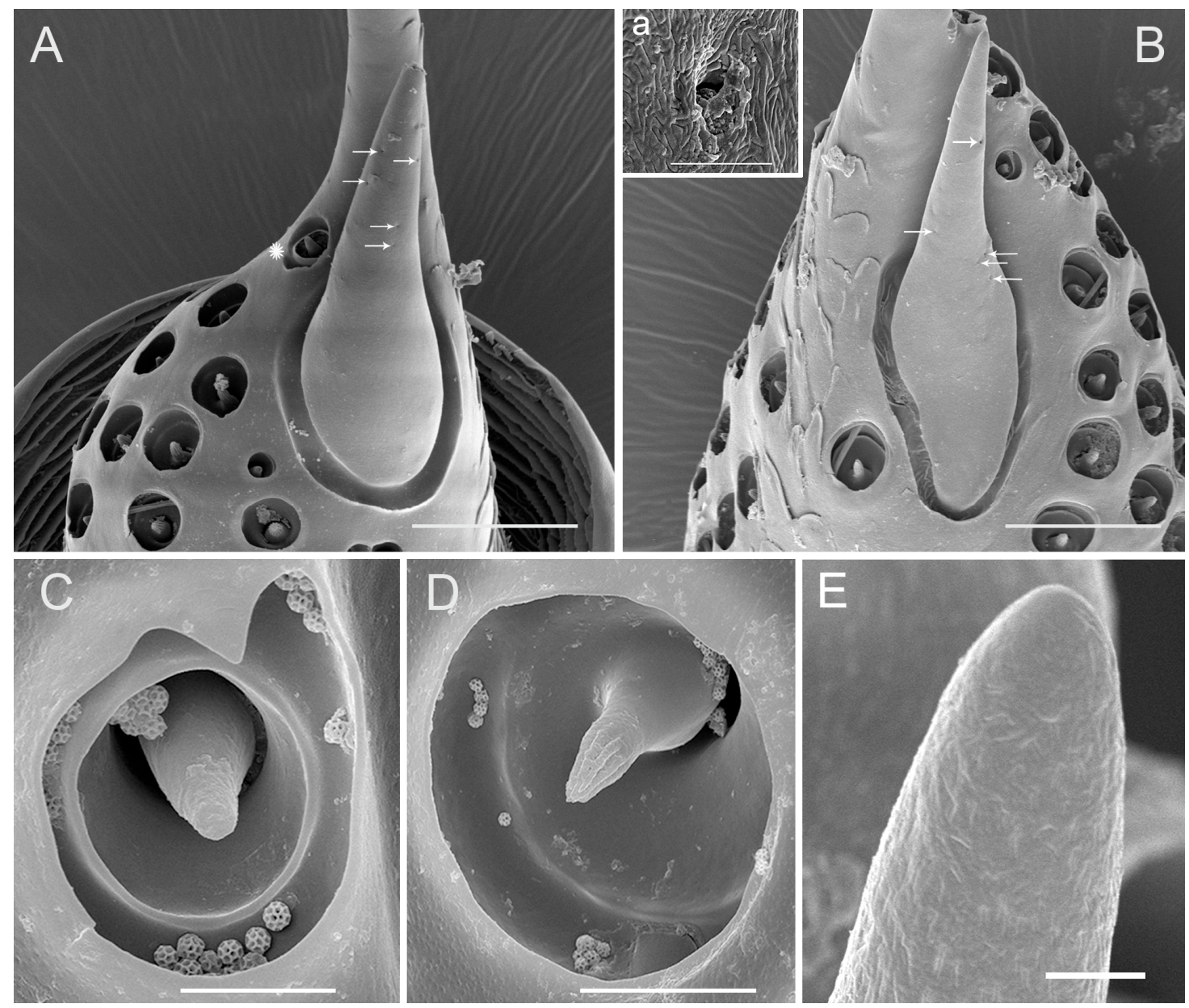

Figure 9. Antennal sensilla on the bulb-shaped portion of the flagellum of an adult Callitettix versicolor (Fabricius). (A) and (B) High magnification image of sensilla basiconica (SB2) in females and males, respectively (white stars indicate the location of $\mathrm{SCo} 2$ and the white arrow indicates the presence of several pitted wall pores), a. enlargement of pitted wall pore; (C) High magnification image of sensilla coeloconica 2 (SCo2); (D) High magnification image of sensilla coeloconica 3 (SCo3); (E) High magnification image of the apex of SB2, pores are visible. Scale bars: $A=25 \mu \mathrm{m} ; B=25 \mu \mathrm{m} ; C=2.5 \mu \mathrm{m}$; $\mathrm{D}=5 \mu \mathrm{m} ; \mathrm{E}=1 \mu \mathrm{m} ; \mathrm{a}=0.5 \mu \mathrm{m}$. 


\subsection{Sensilla Basiconica (SB)}

Sensilla basiconica of two subtypes (SB1 and SB2) are observed on the antennae in both males and females. SB1 are peg-like structures with a smooth cuticle that tapers to a blunt apex and are embedded in a flexible socket (Figure 2B,C; Figure 8A,B). They occur on the base of the scape at the joints between the scape and the head. The SB1 measures $11.96 \pm 1.12 \mu \mathrm{m}$ in length. SB2 (Figure 9A,B) differs in shape and size between the sexes. SB2 are present on the bulb-shaped portion of the flagellum and are inserted in an inflexible socket on the antennal wall near the filament. SB2 in a female has a quite broad base (Figure 9A) but in a male it has a narrower base (Figure 9B). SB2 gradually tapers to an acute tip near the flagellar extension, with a depressed and pitted cuticular surface. Several wall pores are found on these sensilla basiconica 2 (Figure 9A,B), which set with their openings on the floors in the sensillar surface. Moreover, SB2 measures 57.08 $\pm 2.84 \mu \mathrm{m}$ in length for female antennae and measures $72.10 \pm 2.33 \mu \mathrm{m}$ in length for male antennae (Table 1).

\subsection{Sensilla Campaniformia (SCa)}

A sensillum campaniformium 1 (SCa1) $(4.67 \pm 0.56 \mu \mathrm{m}$ in diameter) (Table 1) is situated on the dorsal surface near the sensilla trichodea of the scape and pedicel, respectively (Figure 2C, Figure 3C) and consists of a convex, button-like central area surrounded by a ring of raised cuticle (Figure 2C-a, Figure 3C-a).

There are two sensilla campaniformia on the membrane of the top of the pedicel, which can be divided into two subtypes based on the shape and diameter (SCa2, SCa3) (Figure 4A-C). SCa2 is dome-like with the central part slightly concave, with the external diameter of $5.91 \pm 0.75 \mu \mathrm{m}$ (Figure 4B). SCa3 is similar to SCa2 in structure except for the central part being slightly convex and an ecdysial pore, which can be observed on this convex surface. The diameter of SCa3 is bigger than in SCa1 and SCa2, with an external diameter of $12.55 \pm 1.01 \mu \mathrm{m}$ (Table 1) (Figure 4C).

\section{Discussion}

In this article, we examine Callitettix versicolor (Fabricius), revealing the external morphology and distribution of the antennal sensilla in both males and females for the first time. The antenna sensillum types in different species of Cicadomorpha exhibit considerable structural similarity, and thus a common nomenclature can be applied. Based on these morphological observations, we find that the antennal sensilla of $C$. versicolor are similar to those of other previously studied species of the Cercopoidea [17,19]. C. versicolor differs in exhibiting sexual dimorphism in the number of sensilla coeloconica ( $\mathrm{SCo} 2$ and $\mathrm{SCo} 3$ ) on the flagellum and in the shape of the sensilla basiconica. Moreover, this species has sensilla coeloconica (SCo1) on the membrane of the top of the pedicel. These have not been reported in other cercopid species, although one type of single sensilla campaniformium was reported in four species of Cercopidae [17] and a single sensillum campaniformium occurs in the Aphrophorid Philaenus spumarius (L.) in this part of antennae [19].

\subsection{Types and Functions of Antennal Sensilla}

Sensilla trichodea are the most widely distributed and abundant sensilla found on insect antennae and their occurrence has been reported for numerous Hemiptera [35-39]. In C. versicolor, sensilla trichodea are numerous, and are mainly located on the scape and pedicel, and there are no significant differences between male and female. Exteriorly, mechanoreceptive hairs in insects typically bear no pores or openings on their surface and usually possess a sharp apex and may bear cuticular sculpture such as grooves and spicules with the hair attached to a flexible socket [40]. The sensilla trichodea on the antennal scape and pedicel observed on the antennae of $C$. versicolor lack pores and are, therefore, likely to be mechanoreceptive sensilla that can perform a mechanosensillar function (tactile) [21,41-43].

Sensilla basiconica commonly occur in the Cercopidae and are mainly located on the bulb-shaped portion of the flagellum. Two subtypes of sensilla basiconica (SB1, SB2) were found in this study. 
The morphology of the SB1 on the scape in C. versicolor is a typical "poreless sensilla with a flexible socket" used to detect the respective antennomere position in relation to the head, thereby acting as a proprioceptor. The putative functions of the sensilla can be deduced from the number of pores, and the aporous sensilla are usually mechanoreceptors or thermo-hygroreceptors [44-49]. In contract, the morphology of SB2 in C. versicolor is consistent with an olfactory function, given the presence of multiple pores. Previous work on the sensilla of cercopids and other insects indicated that some sensilla basiconica are typical olfactory chemoreceptors [17,49-51]. There is no sexual dimorphism in the distribution and number of SB1 but sexual dimorphism in fine structure of SB2 occurs in C. versicolor. The shape of SB2 varies between the males and females we examined. Compared to the female, SB2 is narrower at the base in the male. Typically, in previous studies of Cercopidae and Aphrophoridae $[17,19]$, the sensilla basiconica occurs at the apex of the bulb-shaped portion of the flagellum and their number varies between taxa, with cercopids having one and aphrophorids having three. One or four sensilla basiconica were reported in other families of Cercopoidea.

Sensilla campaniformia are found on different parts of antennae of Auchenorrhyncha. They have been reported on the scape, near the segmental joints or the membrane of the top of the pedicel $[14,17,52,53]$, and are considered mechanoreceptors that detect cuticular stress $[3,21,40,50]$. In C. versicolor, three subtypes of sensilla campaniformia (SCa1, SCa2 and SCa3) are located on the scape, pedicel or the membrane of the top of the pedicel. The Sca1 and Sca3 are similar to those reported in other cercopoid species: Philaenus spumarius (L.) (Aphrophoridae), Aufidus trifasciatus Stål, Euryaulax carnifex (Fabricius), Petyllis deprivata (Walker) and Tonnoiria tasmaniae Lallemand (Hemiptera: Cercopidae), and Laodelphax striatellus (Fallén) (Hemiptera: Delphacidae) $[1,17,19]$. Previous authors recognized only one type of sensillum campaniformium (SCa3), we reported other two types (SCa1 and Sca2). In appearance, the SCa3 in C. versicolor is nearly identical with the sensillum campaniformium [12] found in the cixiid Hyalesthes obsoletus Signoret. Generally, sensilla campaniformia are situated in areas of the cuticle that are subject to stress. The sensillum campaniformium located at the distal part of the pedicel in aphids is also considered a proprioceptor [54]. These are stimulated by mechanical deformations of the cuticle, which can either be brought about by external forces or by self-generated movements [55]. The ultrastructure of the $\mathrm{SCa} 2$ must be studied further to confirm this function.

As in the present study, the literature includes reports of different numbers and distributions of sensilla coeloconica among cercopid species. For example, these sensilla are more numerous in C. versicolor than in Notozulia entreriana (Berg) [20] but the number can also vary considerably among individuals of the same species. Thus, numbers of sensilla coeloconica are generally not consistent enough to distinguish particular taxa or sexes. Sensilla coeloconica are embedded in deep open cavities and the aperture is surrounded by a ridge that can take different shapes: e.g., a single ring, petal-like wall, fringed or digitate wall. Sensilla coeloconica on the antennal flagellum of $C$. versicolor are classified into three main morphological subtypes (SCo1, $\mathrm{SCo} 2$ and SCo3) including digitate, petal-like or fringed walls, respectively. The first subtype of sensillum coeloconicum (SCo1) is located on the membrane of the top of the pedicel and, so far, it has not been found in other cercopid species. In the SEM, this sensillum is easily recognized due to the 'fence' of cuticular spines that surrounds the centrally placed sensory peg. Similar sensilla were found in many insects, however, the fence may be lacking in the distal part of the antenna [56]. This sensillum is located in the proximity of sensilla campaniformia. The function of SCo1 is not known. Further studies on the distribution of this structure (SCo1) in other species and studies to test its function are necessary.

SCo2 and SCo3 are located on the bulb-shaped portion of the flagellum and they have a different function. According to their morphology, the Sco3 exhibits olfactory features (pores in grooves) while Sco2 has no pores and probably acts as a thermo-hygroreceptive or thermo-olfactory sensillum. $\mathrm{SCo} 2$ is similar to SCo3 in some other studied Cercopoidea. In Cercopidae and Aphrophoridae species, they exhibit a simple rim with a smooth margin, and are sunken below the cuticular surface of the bulb-shaped portion of the flagellum in some Australian cercopid species [17] and P. spumarius 
(L.) [19]. The SCo2 and SCo3 in C. versicolor are homologous to those of P. spumarius which consists of two different sensory pegs embedded into two separate chambers with a common, single external aperture [19]. It is likely that the $\mathrm{SCo} 2$ and $\mathrm{SCo} 3$ of $C$. versicolor play a similar function in P. spumarius. Ranieri et al. [19] suggested that the SCo3 of P. spumarius are thermo-/chemosensory receptors, with a role in olfaction. In many other insects, sensilla coeloconica on the antennae also belong to two subtypes based on the morphology and ultrastructure, and serve as olfactory sensilla when a double wall and wall pores are present, or as thermo-chemosensory sensilla when wall pores are lacking $[48,49,51,57-60]$

\subsection{Morphological Characters}

An essential difference among all studied cercopid species is the varied distribution of the large group of sensilla coeloconica and the shape of the sensilla basiconica. The number and shape of these sensilla vary among taxa and can be taxonomically and phylogenetically informative. This study has shown that the antennal sensilla of $C$. versicolor are quite different compared to three species of Australian cercopid species (A. trifasciatus, P. deprivata and E. carnifex), the African species Locris maculata [18] and the aphrophorid Sounama borneensis [1] in which sensilla coeloconica are concentrated in a large depressed pit. C. versicolor also differs from the Australian cercopid T. tasmaniae [17] in which eight sensilla coeloconica are arranged in two medium-sized cavities including two or three sensilla coeloconica each, and there are two separate sensilla coeloconica. However, C. versicolor is similar to N. entreriana and the aphrophorid P. spumarius in having the sensilla coeloconica separately located in single hollows on the bulb of the flagellum. Slight differences in the shapes of the sensilla basiconica present in most cercopid species except N. entreriana (long and narrow sensillum basiconicum). Significant differences are observed in the number of sensilla basiconica between the two families, with three presents in aphrophorids and usually one in most cercopids (lacking in some). Sensilla in the cercopid Sphenoclypeana parana (Distant) (Ischnorhininae) [27] deviate from the basic plan of other cercopids (Cercopinae), with several short sensilla basiconica and numerous sensilla coeloconica inserted in single cavities in this species. Less significant is the slight variation in number and arrangement of sensilla trichodea and campaniformia near the base of the pedicel or rarely on other areas of the antenna.

\subsection{Sexual Dimorphism of Olfactory Sensilla}

In Callitettix versicolor, some differences in sensilla coeloconica and basiconica (number, shape and distribution) are evident between sexes, although males and females have identical sensilla types. Significant sexual dimorphism occurs in the higher number of sensilla coeloconica/olfactory in the male than in the female. Sensilla basiconica also differ in their shape between sexes, being wider at the base and shorter with a tapered end in females in contrast to the males (SB2). This sexual dimorphism in sensilla is the first reported for a cercopoid. In related taxa of cercopids, Liang and Fletcher [17] did not observe any difference in shape and numbers of these sensilla between sexes. Sexual dimorphism was also not observed in the antennal structures and sense organs of P. spumarius (Aphorphoridae) [19]. In planthoppers, e.g. L. striatellus (Delphacidae), minor sexual dimorphism occurs in the number of sensilla (usually slightly more in the female) but not in the arrangement of sensilla types [61]. Sexual dimorphism occurs in the olfactory sensilla placodea in adults of Lycorma delicatula (White) (Fulgoridae); in this case with a significantly higher number and size of sensilla placodea in females than males [9].

The lack of sexual dimorphism in antennal sensilla in some other species of cercopids [17] offers evidence that these structures do not play a significant role in locating mates. Observations on some delphacids also suggests that antennal amputation does not influence the mating behavior of Nilaparvata lugens Stal [62] in which male and females communicate via substrate-borne vibrational signals transmitted and detected by organs in the abdomen [63]. According to Stacconi and Romani [61], the antennae of L. striatellus are unlikely to play a role in detecting mating signals but are important in olfactory orientation to the host plant [64] because numerous olfactory sensilla on the antennae of 
this species are used by both sexes to locate their host plants. The large number of these sensilla on the antennae of male $C$. versicolor increases the spatial density of the chemical reception, and might be useful for the detection of volatile compounds released by host plants. Alternatively, these antennal sensory structures might be related to some basic courtship behavior of the male. Chen and Liang [65] observed a self-regulatory pheromone controlling aggregation in the spittlebug nymphal stages of C. versicolor, suggesting that pheromones could also be used in the adult stage of this species.

Since males of various groups of Auchenorrhyncha: Cixiidae, Flatidae, Cercopidae, Membracidae and Cicadellidae use vibrational signals to locate females, olfactory communication may be absent or at least less important in the courtship behavior of these insects [66-74]. Further study of C. versicolor will be needed to determine the behavioral or ecological significance of the observed sexual dimorphism in the antennal sensilla of this species.

\section{Conclusions}

This study provides insight into the first detailed fine morphological characterization of the antennae of $C$. versicolor and the fine structure, location and distribution of different sensilla types in both males and females. Judging by the morphology and function, the basal set of types/subtypes of the antennal sensilla of $C$. versicolor did not strongly differ from other species of Cercopidae, meaning that a similar pattern of antennal sensilla is visible. In particular, we reported other two types of sensilla campaniformia and additional type of sensillum coeloconicum. Novelty is also the sexual dimorphism in sensilla the first reported for a cercopoid. We hope this work will helpful for further physiological and behavioural studies on C. versicolor and other cercopoid species, and may be useful for the future study of taxonomic and phylogenetic analysis of Cercopidae.

Author Contributions: Data curation, W.D.; Funding acquisition, W.D.; Investigation, Q.Z. and N.W.; Methodology, Q.Z. and W.D.; Project administration, W.D.; Resources, W.D.; Writing - original draft, Q.Z., J.B. and W.D.

Funding: This project was supported by the National Natural Science Foundation of China (Nos. 31772514, 31572306, 31272343).

Acknowledgments: We thank Chris Dietrich (University of Illinois at Urbana \& Champaign, IL, USA) and John Richard Schrock (Emporia State University, Emporia, KS, USA) for his comments on an earlier draft of this paper. We also thank the Life Science Research Core Services of Northwest A\&F University (Yangling, China) for providing scanning electron microscope.

Conflicts of Interest: The authors declare no conflict of interest.

\section{References}

1. Liang, A.P.; Webb, M.D. New taxa and revisionary notes in Rhinaulacini spittlebugs from southern Asia (Homoptera: Cercopidae). J. Nat. Hist. 2002, 36, 729-756. [CrossRef]

2. Chen, X.S.; Liang, A.P. Laboratory rearing of Callitettix versicolor (Hemiptera: Cicadomorpha: Cercopidae), with descriptions of the immature stages. Ann. Entomol. Soc. Am. 2012, 105, 664-670. [CrossRef]

3. Zacharuk, R.Y. Antennae and sensilla. In Comprehensive Insect Physiology, Biochemistry and Pharmacology; Kerkut, G.A., Gilbert, L.I., Eds.; Pergamon Press: Oxford, UK, 1985; Volume 6, pp. 1-69.

4. Chapman, R.F. Mechanoreception. Chemoreception. In The Insects: Structure and Function, 4th ed.; Chapman, R.F., Ed.; Cambridge University Press: New York, NY, USA, 1998; pp. 610-652.

5. Ruschioni, S.; Riolo, P.; Verdolini, E.; Peri, E.; Guarino, S.; Colazza, S.; Romani, R.; Isidoro, N. Fine structure of antennal sensilla of Paysandisia archon and electrophysiological responses to volatile compounds associated with host palms. PLoS ONE 2015, 10, e0124607. [CrossRef] [PubMed]

6. Bartlet, E.; Isidoro, N.; Williams, I. Antennal glands in Psylliodes chrysocephala and their possible role in reproductive behavior. Physiol. Entomol. 1994, 19, 241-250. [CrossRef]

7. Romani, R.; Rosi, M.C.; Isidoro, N.; Bin, F. The role of the antennae during courtship behaviour in the parasitic wasp Trichopria drosophilae. J. Exp. Biol. 2008, 211, 2486-2491. [CrossRef]

8. Hamilton, K.G.A. Revision of neotropical Aphrophorinae spittlebugs, part 1: Ptyelini (Hemiptera, Cercopoidea). Zootaxa 2012, 3497, 41-59. 
9. Wang, R.R.; Liu, J.J.; Li, X.Y.; Liang, A.P.; Bourgoin, T. Relating antennal sensilla diversity and possible species behaviour in the planthopper pest Lycorma delicatula (Hemiptera: Fulgoromorpha: Fulgoridae). PLoS ONE 2018, 13, e0194995. [CrossRef] [PubMed]

10. Onagbola, E.O.; Meyer, W.L.; Boina, D.R.; Stelinski, L.L. Morphological characterization of the antennal sensilla of the Asian citrus psyllid, Diaphorina citri Kuwayama (Hemiptera: Psyllidae), with reference to their probable functions. Micron 2008, 39, 1184-1191. [CrossRef] [PubMed]

11. Silva, C.C.; De, C.G.; Moraes, M.C.; Falcão, R.; Solino, L.F.; Laumann, R.A.; Silva, J.P.; Borges, M. Morphology, distribution and abundance of antennal sensilla in three stink bug species (Hemiptera: Pentatomidae). Micron 2010, 41, 289-300. [CrossRef]

12. Romani, R.; Stacconi, M.V.; Riolo, P.; Isidoro, N. The sensory structures of the antennal flagellum in Hyalesthes obsoletus (Hemiptera: Fulgoromorpha: Cixiidae): A functional reduction? Arthropod Struct. Dev. 2009, 38, 473-483. [CrossRef]

13. Wang, R.R.; Wan, X.Y.; Liang, A.P.; Bourgoin, T.A. SEM study of antennal and maxillary sensilla in Zema gressitti Fennah (Hemiptera: Fulgoromorpha: Tropiduchidae). Micron 2013, 44, 261-267. [CrossRef] [PubMed]

14. Zhang, C.N.; Pan, L.X.; Lu, Y.P.; Dietrich, C.H.; Dai, W. Reinvestigation of the antennal morphology of the white-backed planthopper Sogatella furcifera (Horváth) (Hemiptera: Delphacidae). Zool. Anz. 2016, 262, 20-28. [CrossRef]

15. Ahmad, A.; Parveen, S.; Brozek, J.; Dey, D. Antennal sensilla of phytophagous and predatory pentatomids (Hemiptera: Pentatomidae): A comparative study of four genera. Zool. Anz. 2016, 261, 48-55. [CrossRef]

16. Nowińska, A.; Brożek, J. Morphological study of the antennal sensilla in Gerromorpha (Insecta: Hemiptera: Heteroptera). Zoomorphology 2017, 136, 327-347. [CrossRef] [PubMed]

17. Liang, A.P.; Fletcher, M.J. Morphology of the antennal sensilla in four Australian spittlebug species (Hemiptera: Cercopidae) with implications for phylogeny. Aust. J. Entomol. 2002, 41, 39-44. [CrossRef]

18. Boulard, M.; Boulard, J. Un organe énigmatique chez les femelles de Locris (Homoptera Cercopidae). Ann. Soc. Entomol. Fr. 1979, 15, 513-523.

19. Ranieri, E.; Ruschioni, S.; Riolo, P.; Isidoro, N.; Romani, R. Fine structure of antennal sensilla of the spittlebug Philaenus spumarius, L. (Insecta: Hemiptera: Aphrophoridae) Chemoreceptors and thermo-/hygroreceptors. Arthropod Struct. Dev. 2016, 45, 432-439. [CrossRef] [PubMed]

20. Paladini, A.; Carvalho, G.S.; Valério, J.R. Ultrastructure and redescription of Notozulia entreriana (Berg) (Hemiptera: Cercopidae). Neotrop. Entomol. 2008, 37, 552-557. [CrossRef] [PubMed]

21. Schneider, D. Insect antennae. Ann. Rev. Entomol. 1964, 9, 103-122. [CrossRef]

22. Bourgoin, T.; Deiss, V. Sensory plate organs of the antenna in the Meenoplidae-Kinnaridae group (Hemiptera: Fulgoromorpha). Int. J. Insect Morphol. Embryol. 1994, 23, 159-168. [CrossRef]

23. Cheng, C.L.; Yang, C.T. Antennal sensory plaque organs of Fulgoridae (Homoptera: Fulgoroidea). Chin. J. Entomol. 1996, 16, 187-207.

24. Marshall, A.T.; Lewis, C.T. Structural variation in the antennal sense organs of fulgoroid Homoptera (Insecta). Zool. J. Linn. Soc. 1971, 50, 181-184. [CrossRef]

25. Shih, H.T.; Yang, C.T. Antennal sensory plaque organs of the Cixiidae (Homoptera: Fulgoroidea). Chin. J. Entomol. 1997, 17, 33-39.

26. Wang, R.R.; Wan, X.Y.; Liang, A.P.; Bourgoin, T. Ultrastructure of sensory equipment on the heads of Kallitaxila granulata (Stal) (Hemiptera: Fulgoromorpha: Tropiduchidae). Microsc. Res. Tech. 2012, 75, 1659-1665. [CrossRef] [PubMed]

27. Paladini, A.; Takiya, D.M.; Cavichioli, R.R.; Carvalho, G.S. Phylogeny and biogeography of Neotropical spittlebugs (Hemiptera: Cercopidae: Ischnorhininae): Revised tribal classification based on morphological data. Syst. Entomol. 2015, 40, 82-108. [CrossRef]

28. Liang, A.P. Revision, phylogeny, and biogeography of the spittlebug tribe Capnodistini (Hemiptera: Cercopoidea: Aphrophoridae) from Southeast Asia. Ann. Entomol. Soc. Am. 2016, 108, 383-402. [CrossRef]

29. Liang, A.P. Scanning electron microscopy of antennal sense organs in Prosapia bicincta (Say) (Hemiptera: Cercopidae). J. Entomol. Sci. 2001, 36, 335-341. [CrossRef]

30. Paladini, A.; Carvalho, G.S.; Cavichioli, R.R. Taxonomic review of Sphenoclypeana and cladistic analysis of Ischnorhinini (Hemiptera: Cercopidae: Tomapidinae). Zootaxa 2010, 2502, 24-36. [CrossRef] 
31. Carvalho, G.S.; Sakakibara, A.M.; Webb, M.D. Two new species of the neotropical spittlebug genus Monecphora Amyot \& Serville (Hemiptera: Cercopidae) with key and notes of species of the genus. Zootaxa 2016, 4078, 143.

32. Shih, H.T.; Yang, J.T. Supplement on the species Aphrophora horizontalis Kato (Hemiptera: Cercopoidea: Aphrophoridae). Plant Prot. B 2005, 47, 77.

33. Cryan, J.R.; Svenson, G.J. Family-level relationships of the spittlebugs and froghoppers (Hemiptera: Cicadomorpha: Cercopoidea). Syst. Entomol. 2010, 35, 393-415. [CrossRef]

34. Zacharuk, R.Y. Ultrastructure and function of insect chemosensilla. Ann. Rev. Entomol. 1980, 25, 27-47. [CrossRef]

35. Rani, P.U.; Madhavendra, S.S. Morphology and distribution of antennal sense organs and diversity of mouthpart structures in Odontopus nigricornis (Stall) and Nezara viridula L. (Hemiptera). Int. J. Insect Morphol. Embryol. 1995, 24, 119-132. [CrossRef]

36. Li, Q.L.; Wei, C. Antennal morphology of the cicada Meimuna mongolica (Distant) (Hemiptera: Cicadidae), with a deduction of its nymphal instars and discussion of the antennal morphological variations in relation to niche changes. Entomotaxonomia 2013, 2, 81-94.

37. Catalá, S.S. Antennal sensilla of Triatominae (Hemiptera, Reduviidae): A comparative study of five genera. Int. J. Insect Morphol. Embryol. 1997, 26, 67-73. [CrossRef]

38. Chinta, S.; Dickens, J.C.; Baker, G.T. Morphology and distribution of antennal sensilla of the tarnished plant bug, Lygus lineolaris (Palisot de beauvois) (Hemiptera: Miridae). Int. J. Insect Morphol. Embryol. 1997, 26, 21-26. [CrossRef]

39. Gao, Z.Z.; Wu, W.J.; Liang, G.W. Observation of the antennal sensilla of Campylomma chinensis (Hemiptera: Miridae) by environmental scanning electron microscope. J. South China Agric. Univ. 2006, 27, 18-20.

40. McIver, S.B. Structure of cuticle mechanoreceptors of arthropods. Ann. Rev. Entomol. 1975, 20, 381-397. [CrossRef]

41. Sane, S.P.; Dieudonné, A.; Willism, M.A.; Daniel, T.L. Antennal mechanosensors mediate flight control in moths. Science 2007, 315, 863-866. [CrossRef]

42. Slifer, E.H. The fine structure of arthropod chemoreceptors. Ann. Rev. Entomol. 1970, 15, 121-142. [CrossRef]

43. Thurm, U. Ableitung der Rezeptor-potentiale und NervenimpulseeinzeIner Cuticula-Sensillen bei Insekten. Z. Naturforsch. 1962, 17, 285-286. [CrossRef]

44. Keil, T.A. Morphology and Development of the Peripehral Olfactory Organs. In Insect Olfaction; Hansson, B.S., Ed.; Springer: Heidelberg, Germany, 1999; pp. 5-47.

45. Altner, H.; Loftus, R. Ultrastructure and function of insect thermo- and hygroreceptors. Ann. Rev. Entomol. 1985, 30, 273-295. [CrossRef]

46. Altner, H.; Schaller-Selzer, L.; Stetter, H.; Wohlrab, I. Poreless sensilla with inflexible sockets. A comparative study of a fundamental type of insect sensilla probably comprising thermo- and hygroreceptors. Cell Tissue Res. 1983, 234, 279-307. [CrossRef] [PubMed]

47. Altner, H.; Tichy, H.; Altner, I. Lamellated outer dendritic segments of a sensory cell within a poreless thermoand hygroreceptive sensillum of the insect Carausius morosus. Cell Tissue Res. 1978, 191, 287-304. [CrossRef] [PubMed]

48. Altner, H.; Routil, C.; Loftus, R. The structure of bimodal chemo-, thermo-, and hygroreceptive sensilla on the antenna of Locusta migratoria. Cell Tissue Res. 1981, 215, 289-308. [CrossRef] [PubMed]

49. Altner, H.; Prillinger, L. Ultrastructure of invertebrate chemo-, thermo-, andhygroreceptors and its functional significance. Int. Rev. Cytol. 1980, 67, 69-139.

50. Keil, T.A.; Steinbrecht, R.A. Mechanosensitive and olfactory sensilla of insects. In Insect Ultrastructure; King, R.C., Akai, H., Eds.; Plenum: New York, NY, USA, 1984; Volume 2, pp. 477-516.

51. Steinbrecht, R.A. Olfactory receptors. In Atlas of Arthropod Sensory Receptors-Dynamic Morphology in Relation to Function; Eguchi, E., Tominaga, Y., Eds.; Springer: Tokyo, Japan, 1999; pp. 155-176.

52. Fu, B.X.; Bellis, G.A.; Hong, J.; Wang, J.R.; Wu, Q.; Tang, Q.Y.; Cheng, J.A.; Zhu, Z.R. Morphology, distribution, and abundance of antennal sensilla of male and female macropterous and brachypterous small brown planthopper, Laodelphax striatellus (Fallén) (Hemiptera: Delphacidae). Microsc. Res. Tech. 2012, 75, 1492-1512. [CrossRef]

53. Fu, B.X.; Zhu, Z.R.; Rong, N.H.; Hong, J.; Zhang, C.X.; Cheng, J.A. Phase-related developmental characteristics of antennal sensilla of nymphal Laodelphax striatellus (Hemiptera: Delphacidae), a serious virus-transmitting insect vector of graminaceous crops. Ann. Entomol. Soc. Am. 2013, 106, 626-636. [CrossRef] 
54. Bromley, A.K.; Dunn, J.A.; Anderson, M. Ultrastructure of the antennal sensilla of aphids. II. Trichoid, chordotonal and campaniform sensilla. Cell Tissue Res. 1980, 205, 493-511. [CrossRef]

55. Keil, T.A. Functional morphology of insect mechanoreceptors. Microsc. Res. Tech. 1997, 39, 506-531. [CrossRef]

56. Hallberg, E.; Hansson, B.; Steinbrecht, R.A. Morphological characteristic of antennal sensilla in the European cornborer Ostrinia nubilalis (Lepidoptera: Pyralidae). Tissue Cell 1994, 26, 489-502. [CrossRef]

57. Pophof, B. Olfactory responses from sensilla coeloconica of the silkmoth Bombyx mori. Physiol. Entomol. 1997, 22, 239-248. [CrossRef]

58. Pophof, B.; Stange, G.; Abrell, L. Volatile organic compounds as signals in a plantherbivore system: Electrophysiological responses in olfactory sensilla of the moth Cactoblastis cactorum. Chem. Senses 2005, 30, 51-68. [CrossRef] [PubMed]

59. Hunger, T.; Steinbrecht, R.A. Functional morphology of a double-walled multiporous olfactory sensillum: The sensillum coeloconicum of Bombyx mori (Insecta, Lepidoptera). Tissue Cell 1998, 30, 14-29. [CrossRef]

60. Diehl, P.A.; Vlimant, M.; Guerenstein, P.; Guerin, P.M. Ultrastructure and receptor cell responses of the antennal grooved peg sensilla of Triatoma infestans (Hemiptera: Miridae). J. Insect Physiol. 2003, 41, 857-867. [CrossRef]

61. Stacconi, M.V.R.; Romani, R. Antennal sensory structures in Scaphoideus titanus Ball (Hemiptera: Cicadellidae). Microsc. Res. Tech. 2012, 75, 458-466. [CrossRef] [PubMed]

62. Ichikawa, T. Sexual communications in planthoppers. In The Rice Brown Planthopper; Kono, T., Ed.; FFTC/ASPAC: Taipei, Taiwan, 1977; pp. 84-94.

63. Ichikawa, T.; Sakuma, M.; Ishii, S. Substrate vibrations: Mating signal of three species of planthoppers which attack the rice plant (Homoptera: Delphacidae). Appl. Entomol. Zool. 1975, 10, 162-171. [CrossRef]

64. Obata, T.; Kim, M.; Koh, H.; Fukami, H. Planthopper attractant(s) in the rice plant. Jpn. J. Appl. Ent. Zool. 1981, 25, 47-51. (In Japanese with English Summary) [CrossRef]

65. Chen, X.S.; Liang, A.P. Identification of a self-regulatory pheromone system that controls nymph aggregation behavior of rice spittlebug Callitettix versicolor. Front. Zool. 2015, 12, 1-12. [CrossRef]

66. Cocroft, R.B. Offspring-parent communication in a subsocial treehopper (Hemiptera: Membracidae: Umbonia crassicornis). Behaviour 1998, 136, 1-21. [CrossRef]

67. Hunt, R.E.; Fox, J.P.; Haynes, K.F. Behavioral response of Graminella nigrifrons (Homoptera: Cicadellidae) to experimentally manipulated vibrational signals. J. Insect Behav. 1992, 5, 1-13. [CrossRef]

68. Hunt, R.E. Vibrational signals associated with mating behaviorin the treehopper. Enchenopa binotata Say (Hemiptera: Homoptera: Membracidae). J. N. Y. Entomol. Soc. 1994, 102, 266-270.

69. Lopez Machado, F.E.; Peck, D.C.; Montoya Lerma, J. The importance of vibrational communication in the reproductive behavior of grassland spittlebugs (Homoptera: Cercopidae). Rev. Colomb. Entomol. 2001, 27, 9-15.

70. Mazzoni, V.; Lucchi, A.; Ioriatti, C.; Virant-Doberlet, M.; Anfora, G. Mating behavior of Hyalesthes obsoletus (Hemiptera: Cixiidae). Ann. Entomol. Soc. Am. 2010, 103, 813-822. [CrossRef]

71. Tishechkin, D.Y. Acoustic signalling in Paralimnini leafhoppers (Homoptera: Cicadellidae: Deltacephalinae). Zool. Zhurnal 1992, 71, 58-65.

72. Virant-Doberlet, M.; Zezlina, I. Vibrational communication of Metcalfa pruinosa (Hemiptera: Fulgoroidea: Flatidae). Ann. Entomol. Soc. Am. 2007, 100, 73-82. [CrossRef]

73. Zhantiev, R.D.; Tishechkin, D.Y. Acoustic signalling of cicadellids of the genus Macropsis Lew. (Homoptera, Cicadellidae) of the European part of the USSR. Entomol. Oboz. 1989, 68, 469-477.

74. Mazzoni, V.; Ioriatti, C.; Trona, F.; Lucchi, A.; De Cristofaro, A.; Anfora, G. Study on the role of olfaction in host plant detection of Scaphoideus titanus (Hemiptera: Cicadellidae) nymphs. J. Econ. Entomol. 2009, 102, 974-980. [CrossRef]

(C) 2019 by the authors. Licensee MDPI, Basel, Switzerland. This article is an open access article distributed under the terms and conditions of the Creative Commons Attribution (CC BY) license (http:/ / creativecommons.org/licenses/by/4.0/). 